$\mathrm{N}^{\circ} 27,1-24$, julio - diciembre, 2020

\title{
La otra frontera, confluencia de discursos culturales ${ }^{1}$
}

\author{
Francisco Javier Ibáñez Castejón \\ Universidad Cirilo y Metodio de Skopje \\ ibanezfran51@gmail.com
}

\section{Resumen}

La otra frontera (1967) de César A. Candanedo es una de las novelas paradigmáticas en la narrativa panameña de las décadas centrales del siglo XX. La obra aborda tanto el asunto canalero como la problemática con las transnacionales del banano. Hasta ese momento nadie en el país se había ocupado de esta segunda cuestión. En una realidad trastornada por la acción de los agentes del capitalismo, las clases populares deben alzarse y, siguiendo a sus líderes, conquistar su libertad mediante la rebelión. Si bien la producción no destaca por su cuidado formal, la obra sobresale por la elaboración de su mensaje de denuncia. El autor recurre a los discursos culturales más relevantes en el Panamá de la época para su configuración: el nacionalismo, el cuestionamiento del discurso triunfalista oficial y el arielismo, entre otros. Precisamente, este artículo analiza la presencia de estas manifestaciones culturales en La otra frontera y su función en el ensamblado de la trama.

Palabras clave: Panamá, Novela, Canal, Nacionalismo, Candanedo

\begin{abstract}
La otra frontera (1967) by César A. Candanedo is one of the archetypal novels of the Panamanian narrative of the central decades of the $20^{\text {th }}$ century. This work addresses both the canal issue and the conflict that emerged as a result of the gradual operations of the transnational banana corporations. Until then, no one in the country had ever written anything about the latter. In a reality disturbed by the action of the agents of capitalism, the popular classes must rise and, following their leaders, take back their freedom through revenge and rebellion. Although the novel does not stand out for its formal elaboration, it does excel in its message of protest. The
\end{abstract}

1. Recibido $2 / 7 / 2020$ - Aprobado $24 / 7 / 2020$ 
author uses the most relevant cultural discourses in the Panama of his time for the configuration of the content: nationalism, the questioning of the official triumphalist discourse and arielismo, among others. In fact, this article analyzes the presence of these cultural manifestations in $\mathrm{La}$ otra frontera and their role in the assembly of the plot.

Keywords: Panama, Novel, Canal, Nationalism, Candanedo

\section{Introducción}

Con La otra frontera (1967), César Candanedo (1906-1993) presentaba al Concurso Ricardo Miró de 1959 una novela atípica en su medio. Verdad es que solo quedó segunda y que tardó más de un lustro en publicarse. Sin embargo, es esta una de las producciones más representativas de la novelística panameña de las décadas centrales del siglo XX. Heredera directa de los fundamentos del regionalismo latinoamericano, en ella destaca su mensaje denunciatorio. Ahora bien, a diferencia de otras creaciones similares, en esta ocasión son dos las problemáticas que aborda el autor: la cuestión canalera y el conflicto bananero. Si bien del primer asunto se había ocupado ya Joaquín Beleño ${ }^{2}$, del segundo Candanedo es el iniciador en el país. Para él, la vía interoceánica, causante de infinidad de desgracias, supone además la entrada masiva de lo foráneo, lo que deja a la nación en una extrema vulnerabilidad, casi sin control efectivo sobre el territorio. Los extranjeros, aprovechándose de esta coyuntura, expanden su empresa neocolonial a otros sectores - en concreto, la explotación agropecuaria - y a otras regiones — de la Zona, a Chiriquí y Bocas del Toro.

En términos más concretos, esta novela guarda un estrecho vínculo con la narrativa ruralista panameña. Este modelo, en boga desde los cuarenta y defendido por el establishment intelectual, propugnaba que la esencia de la patria se mantenía inviolada en el interior del país, mientras que en las grandes ciudades se hallaba "contaminada" por la numerosa presencia extranjera, atraída a la región por el proyecto canalero. Los autores, inmersos en un proceso nacionalista de introspección identitaria, debían retratar, por tanto, las tradiciones, costumbres y visión del mundo del campesino, en peligro por el empuje de la modernidad, a la cual se concibe en términos negativos (Pulido Ritter, 2006, 28).

No obstante, Candanedo busca superar en La otra frontera las limitaciones del modelo ruralista y presenta una realidad socioeconómica y política más compleja. Alejándose del paradigma, el autor pone el énfasis en la conexión existente entre los problemas del campo y las decisiones que se toman en la capital del país y, cuando esta queda subordinada a los poderes extranjeros, en las principales urbes del mundo capitalista. Allí es donde residen "amos más poderosos que los gobiernos, que los países, socios de la muerte, que reparten la muerte, tan poderosos como la muerte, de brazos tan largos que alcanzan más allá de todas las fronteras" (Candanedo, 1967, 146 ${ }^{3}$, a quienes nadie elige, pero cuyos caprichos trastornan la vida de millones de individuos.

En este planteamiento del autor se percibe la impronta de uno de los ensayos más influyentes de la historia literaria nacional: "Rutas de la novela panameña" (1957) de Rogelio Sinán. En este breve artículo, el veragüense daba por finiquitado el ruralismo por ser incapaz de dar cuenta total de la realidad panameña. Sesgado e incompleto, excluye de la representación de

2. Beleño es autor de la célebre trilogía canalera: Luna verde (1949), Gamboa Road Gang (1959) y Curundú Line (1961).

3. En adelante, las citas extraídas de La otra frontera — todas procedentes de la misma edición- solo se referenciarán con el número de página entre paréntesis. 
lo nacional a buena parte del país. Es por ello que La otra frontera trata de revitalizar la corriente con este diseño más abarcador y novedoso.

Asimismo, en el texto de Sinán se destaca la división tradicional del país en dos rutas, la vegetal y la mineral. La primera recorre el país de norte a sur y es rural, aparentemente atrasada y no goza de prestigio. Su antagonista atraviesa la nación de este a oeste y "cuenta con modernísimos medios de transporte (ferrocarril, canal y carreteras) en los que todo está limpiecito, barnizado y 'prohibido'. Esta ruta, que es como una infernal Babel de lenguas y mezquinos apetitos, tiene para nosotros un carácter virtualmente extranjero, cicatriz imborrable, que duele a veces según soplen los vientos y que se ahonda cada día más y más" (Sinán, 1957, 104). Estas zonas generan dos modelos de ser humano: el "hombre vegetal", apegado a la naturaleza, pacífico y supersticioso, y el "mineral", ávido de riquezas y sin escrúpulos. A lo largo de las centurias, la preminencia de este segundo arquetipo ha supuesto la opresión y el sometimiento de la mayoría. No obstante, para Sinán, la novela que supere el gastado ruralismo, exponiendo a la vez una visión integradora del ser nacional, solo puede surgir de la confluencia de ambas rutas $(1957,109)$.

La otra frontera, por sus limitaciones, no llega a ser la propuesta totalizante que Sinán reclama, pero sí es cierto que su autor no desatiende las lecciones ofrecidas en "Rutas". Precisamente, si un elemento destaca en la aportación de Candanedo es la enorme brecha que divide a los personajes, el conflicto que los opone y los distancia. Los protagonistas - los campesinos de la comunidad de San Juan - son víctimas reiteradas de los antagonistas - los estadounidenses - y sus aliados, las autoridades locales. Los proyectos aparentemente desarrollistas, pero profundamente interesados, que emprenden los norteamericanos desde sus oficinas provocan el hundimiento de la aldea - situada en un espacio que habrá de ser empleado para el canal-, el exilio y las sucesivas torturas en manos de los agentes del capitalismo occidental. El relato se erige, de este modo, en una plasmación narrativa del choque entre el hombre vegetal y el mineral o, lo que es lo mismo, entre lo ancestral panameño y la modernidad.

Protagonistas y antagonistas son a su vez portadores de unos valores que también se contraponen irreconciliablemente. Referidas a aspectos capitales del ser humano, estas oposiciones amplían la trascendencia del mensaje expuesto. Ante lo artificial se alza lo natural; frente a lo material se eleva lo espiritual; la justicia honrada se indigna por los manejos de quienes pagan para moldear la ley a su gusto; el trato igualitario de quienes se respetan brilla en menoscabo de la explotación interesada de los trabajadores; la verdadera sabiduría se enaltece en contrapunto con los desafueros de la ignorancia brutal. En definitiva, son dos formas de entender y estar en el mundo las que colisionan, sometiendo a examen a ambos paradigmas.

De la prueba surge un claro triunfador, el lado panameño. Su victoria se concibe, asimismo, como la prevalencia final del bien frente al mal. Es esta, por tanto, una obra donde se restaña y se venga el dolor sufrido, en la que se ajustan cuentas con el opresor. Por una vez, este es derrotado como merece, en el amanecer de un nuevo día que trae la esperanza. El pueblo, una vez concienciado, se levanta y, siguiendo a sus líderes, satisface con sus manos los agravios.

De trama lineal y dividido en cuatro partes, el relato es dirigido con firmeza por el narrador omnisciente, quien interrumpe su discurso con frecuencia para dar paso a toda una galería de voces extensa, amorfa y dispar: los personajes, que desfilan por las páginas dando muestras de su calidad humana, tanto de grandeza como mezquindad. Ahora bien, apenas perfilados, carecen de hondura psicológica. Y es que esta novela no destaca por su brillantez formal. Algo tosca y desgarbada, poca atención concede a los aciertos estéticos, más allá del esfuerzo por plasmar de modo realista el lenguaje empleado por los personajes, a quienes se les 
define en su sociología mediante su dicción. Su carácter de obra artística se asienta, más bien, en la verdad simbólica que plasma: la épica lucha del pueblo campesino panameño.

Con todo, no debe pensarse que es esta una producción ramplona. La lectura atenta de $L a$ otra frontera revela una composición discursiva compleja. El texto establece conexiones con multitud de manifestaciones culturales que robustecen el valor de lo mostrado en la obra. El autor toma lo que le interesa de ellas y las moldea para delinear las coordenadas por las que discurre la trama. Estos discursos actúan, por tanto, como marcos ideológicos que determinan la selección de los elementos del relato y su disposición jerárquica. Las situaciones que viven los personajes se interpretan desde estos vectores, que el autor recoge de variadas fuentes: el nacionalismo panameño, el cuestionamiento de la narrativa del Pro Mundo Beneficio, la inversión de los valores de civilización y barbarie, el arielismo, las corrientes proletarias y las referencias bíblicas. Conocerlos y determinar cómo afectan al desarrollo del relato se hace necesario para poder desentrañar el mensaje propuesto en toda su angulosidad. De actualidad en su tiempo, eran fácilmente reconocibles por los lectores cultos de la época. Ahora, sin embargo, no resulta tan sencillo, pues ya quedan algo lejanos.

La crítica se ha ocupado en algunas ocasiones de esta obra ${ }^{4}$. Sin embargo, mientras los investigadores han tratado cuestiones como la lengua usada por el autor o han destacado su contenido de protesta, hasta ahora no se ha prestado atención al vínculo entre La otra frontera y las relevantes propuestas discursivas antes mencionadas. Por ello, se impone una relectura de la obra que trate de solventar esta carencia, objetivo que se pretende satisfacer en este estudio.

\section{2. ¿Pro mundo beneficio? El canal, el hundimiento y el exilio}

En la novela regionalista, que para 1959 había dado, a nivel continental, lo mejor que habría de producir, se convirtió en cliché abrir la trama con una situación de equilibrio y fractura $^{5}$. En muchas ocasiones, la paz de la comunidad tradicional se rompía por la llegada de un agente externo que, con proyectos muy alejados del modo de vida local, perturbaba el bienestar de los habitantes, frecuentemente seres ingenuos poco al tanto de las exigencias de la civilización. Todos los esfuerzos de los entes positivos del relato se centraban en superar la amenaza a fin de restablecer la plenitud inicial. Si se conseguía, esta vez se alcanzaba una realidad más auténtica y noble, pues el conflicto había provocado convulsiones transformadoras en la aldea, ya madura después del proceso.

Candanedo, siguiendo esta tradición textual, presenta un esquema similar en La otra frontera. Una longeva comunidad enclavada en el centro del país - San Juan de Pequení- mora en paz. La vida allí transcurre lenta y las preocupaciones se relacionan con la falta o abundancia de precipitaciones para las cosechas, el rescate de algún animal extraviado o la picadura de una serpiente ponzoñosa. Inmersos en dinámicas precapitalistas, los pobladores practican una agricultura y un comercio con otras localidades cercanas muy básicos. Bajo el duro sol y sobre los huesos de sus antepasados, cultivan la tierra y se ganan el sustento. En estos lares siempre se sobrevivió, aunque con lo justo. El paisaje es bello y desatado, con junglas y ríos impetuosos. Un orden preside el concierto de las cosas: al trabajo agotador le corresponde siempre el premio de la tierra. Es cierto que la naturaleza puede ser temible, pero si se conocen sus secretos, se la

\footnotetext{
4. Sirvan como ejemplo "Entre Los clandestinos y El perseguido" de Margarita Vázquez o "Aproximación a César Candanedo, el escritor" de Luis Óscar Miranda (referencias completas en la bibliografía).

5. Tal es el caso en dos de las más renombradas, las cuales sin duda contribuyeron a establecer este esquema narrativo: El Tungsteno (1931) del peruano César Vallejo y Huasipungo (1934) de Jorge Icaza.
} 
convierte en aliada. Ese equilibrio centenario pronto se romperá con la llegada de los estadounidenses.

Para solucionar los percances de la cotidianidad los vecinos acuden a No Cruz, un anciano solitario de aire indígena, sin mujer y sin edad. Portador de una vasta sabiduría ancestral, su proceder parece magia a ojos del profano. Hombre silente, le rodea un aura misteriosa y ambigua que se acentúa intencionalmente en la obra, dejando sin explicación los mecanismos que emplea para someter las tormentas, descubrir a los ladrones y ver en la oscuridad sin dificultades. También es bondadoso, compasivo y humilde. Justamente, la narración se inicia con una serie de situaciones conflictivas, propias del agro, en las que Cruz deja ver todos sus dones. Cuando logra uno de sus éxitos, se retira a su rancho sin esperar el afecto de la compadrada. Nunca participa en las celebraciones de júbilo en su honor, aunque todos lo veneran: para San Juan, es un protector que guía.

Su madre fue la tierra y su padre trabajó en el canal francés, el primer intento occidental por construir una vía marítima en el istmo. Aquellos tiempos eran, sin duda, mejores. Había riqueza y "los extraños no mandaban" (29). En la novela se destaca la mejor sintonía que los panameños establecieron con los galos ${ }^{6}$. El rechazo a lo anglosajón lleva al autor, de intensa hispanofilia, a juzgar al francés, también latino, de carácter más próximo al propio. Su acercamiento humano hacia los locales lo demuestra: impusieron menos restricciones y no recurrieron a la bota militar para mantener el orden. Con los estadounidenses es diferente. Resulta imposible soslayar las imposiciones venidas de la Zona del Canal (1903-1979), la faja desde la que los norteamericanos manejan la vía e injieren en el quehacer panameño. Si no se acata la orden del soldado, indefectiblemente llega la bala.

Estas confesiones se las dirige Cruz a Juan Cancio. Rapaz de mirada viva e inteligencia sutil, es el elegido para que continúe con la tradición una vez muerto el brujo, para lo que — presiente el mismo anciano - falta ya poco. Sus enseñanzas despiertan en el discípulo la conciencia de quién es y cuáles son los valores que debe defender, los que representan la verdadera justicia. Esas lecciones incentivan en el joven el amor a la patria y el odio hacia el enemigo, el norteamericano. Este, en el país desde 1903, en breve llegará a la aldea.

Uno de los mandatos asumidos por Cancio sostiene que hay que enfrentar a quien viene a saquear a la nación. El ejemplo se encuentra en el incidente de Tajada de Sandía ${ }^{7}$. Las referencias a este suceso son remarcables, pues ponen de relieve la presencia de uno de esos discursos culturales con peso en la novela: el nacionalismo panameño. Para los seguidores de esta corriente, inmersos en un proceso de fortalecimiento de la identidad nacional mediante la construcción de una narrativa que legitimase su idea de lo panameño, ese acontecimiento fue entendido como una victoria ante el extranjero y, por supuesto, como una muestra de que los istmeños, aunque vinculados todavía a Colombia, estaban forjando una conciencia única. Haciendo suya esa interpretación, por lo que sirve de ejemplo, el historiador Alfredo Figueroa afirma: "Los eventos luctuosos de 1856 poseen significación axial por lo que respecta a la cristalización del nacionalismo panameño" $(1982,341)$.

Con el rescate de episodios de este tipo, los nacionalistas trataron de fomentar el orgullo de pertenecer a una nación pisoteada en la historia, pero siempre prevaleciente. De hecho, en

6. Este tópico es recurrente en la novelística canalera. Por ejemplo, en Pueblos perdidos (1962) — publicada solo tres años más tarde que La otra frontera concursase en el Miró-, la protagonista, una guatemalteca emigrada a Panamá, mantiene una relación sentimental con un ingeniero francés, Camile Rostand, que la deja marcada de por vida tanto emocionalmente como por el hijo que tienen juntos.

7. El 15 de abril de 1856 dieciséis ciudadanos estadounidenses murieron a manos del populacho panameño, quien también destruyó las instalaciones del ferrocarril transístmico y solo sufrió una baja. 
ellos destaca habitualmente la exhibición del carácter rebelde de los locales ante las imposiciones externas. Así es como se referencia el suceso en La otra frontera. De hecho, para Cruz, la violencia que se empleó aquel día es la forma idónea para lidiar con el adversario. Simplemente hacen falta soldados comprometidos con la causa nacional. Cancio será el primero del nuevo ejército.

Resulta ciertamente llamativo, no obstante, que, en todo este recorrido por el pasado, no se mencione ni a los antillanos ni a la inmigración en general como fenómenos ligados al asunto canalero. También en la línea del nacionalismo panameño, la novela silencia un aspecto fundamental de la historia propia: la aportación de los llegados de otras tierras al desarrollo nacional. En el texto la figura del trabajador extranjero, también sometido a las severas directrices de los estadounidenses, queda prácticamente excluida. La de Candanedo es, por tanto, una obra sobre panameños dirigida a compatriotas.

En boca de Cruz se expresa buena parte de la visión del mundo que contiene el relato. Cuando un conflicto se desata - indica - "hay que buscar la cura, la contra" (12), y esta debe ser proporcional al problema. En el instante en que un estadounidense aparece en San Juan, el anciano constata que ha llegado el temido momento: lo foráneo ha aterrizado en la aldea para invadirla. El protector sabe que esta vez San Juan ha de enfrentarse a una amenaza mucho más poderosa que la naturaleza: el hombre. El remedio contra este mal va a ser realmente difícil de conseguir.

Ese rico extranjero, culto y buen dominador del español, desea hacerse con las tierras de los pobladores. Sabe de antemano que las autoridades pagarán retribuciones cuando sean hundidas para dar paso al canal. Cruz, por su parte, no negocia y se opone vehemente a que sus vecinos cedan, a los que alerta del poder corruptor del dinero y las desviaciones que ocasiona en las almas puras. Para el guardián, el único dinero tolerable — si es que hay alguno - es el que proviene del trabajo honesto. Si bien sus conciudadanos no aceptan estas proposiciones del norteamericano, al cabo se verán seducidos por los reclutadores que trabajan para el Canal, quienes ofrecen buena paga. Estos requieren mano de obra para levantar la presa que dará sostén al nuevo lago, el Alajuela. Cruz vuelve a exhortarlos para que no se sometan a ese amo y permanezcan libres en sus tierras, con su pasar austero, pero honrado. La mayoría, sin embargo, deja el pueblo para enrolarse en el contingente que está construyendo el paso marítimo.

Cuando los vecinos se enriquecen, dan la espalda a Cruz. Obnubilados por los dólares, ya no requieren consejos. El viejo, aislado, comienza a marchitarse; sus poderes son inútiles en el nuevo orden: el materialismo ha infectado San Juan y los salarios se malgastan en frivolidades. Esta repulsa al pecunio es otro de los tópicos del nacionalismo panameño presente en La otra frontera $^{8}$. De regusto cristiano, la idea de que el dinero destruye, más que arregla, las vidas de los humildes, tiene una presencia insistente en la obra. Cuando los aldeanos reconocen el error de haberse apartado del guía, es demasiado tarde y la verdad los sobrecoge: con sus manos están cavando la tumba para el pueblo, que será sepultado por el agua de la presa. Dos errores graves los condenan: desoyeron al líder y aceptaron dólares manchados. La adoración al becerro de oro conlleva la expulsión del pequeño paraíso.

Las autoridades estadounidenses demandan el abandono de la aldea. Cruz es el único que no acepta: decide quedarse para morir en lo suyo. Es como si una época, ya irrecuperable, se fuese con él. Un nuevo Panamá, más violento y hostil, resurgirá tras su falta. El modelo de héroe que él representa ha quedado obsoleto, sobrepasado por los peligros de la modernidad. Sus

8. Este rechazo es, asimismo, común en la novelística canalera. Lo encontramos tanto en Crisol de José Isaac Fábrega (1936, 81-82) como en Luna verde de Joaquín Beleño (1999, 179), por citar dos ejemplos bastante dispares entre sí. 
conocimientos no son suficientes ante el terrorífico enemigo, el capitalismo occidental metabolizado en sus agentes. Él no es más que un hombre de machete, de los que desean ser sepultados sin ataúd para estar en contacto perenne con la tierra. Ya sin fuerza, carece también de capacidad estratégica y organizativa: demasiado solitario para conducir a la masa.

Se requiere un nuevo tipo de líder, inclinado a la acción; un joven que no ponga reparos frente a la violencia, pues son tiempos que demandan "mujeres muy hombres y hombres más hombres" (12). Además de fiereza, virilidad y determinación — los rasgos más realzados en la obra-, es preciso que posea inteligencia y magnetismo para atraer miembros a la causa. Cancio es el hombre indicado. Por ello, no duda en dar su palabra al maestro: se vengará de los extranjeros por el daño cometido a la patria. El joven guía, con sus acciones a lo largo del relato, demostrará la veracidad de una de las sentencias centrales de Cruz: "Cuando el cristiano conoce su fuerza y su camino, lo domina todo... Los ríos, las montañas, los animales y sus peligros. Y también al otro animal más poderoso: otro hombre, la peor fiera" (23).

Cruz toma un brebaje para ahorrarse una muerte lenta, pero su final no es cobarde. Cuando su destino llega, una sonrisa se dibuja en el rostro. Se va con la paz de no haberse vendido al norteamericano: "Casi cadáver [...], todavía quedo panameño completo: hombre que desprecia la miserable bolsa de plata extranjera" (59). No pasan desapercibidas, de nuevo, las referencias bíblicas en el pasaje. La traición de Judas se vincula con la entrega de la nación por beneficios económicos: uno debe mantenerse fiel a sí mismo y su comunidad. Aunque el brujo muere, revive en el pupilo: "Cancio... Cuando seas más hombre serás el desquite. En ti la esperanza no muere... Tienes fibra, lo sé bien... Serás la revolución" (46). En la novela, la bondad es eterna, pues se renueva en cada corazón prístino que, cuando despierta a la vida, se compromete con la justicia.

En estos primeros compases de la trama resalta la determinante presencia del canal. Aunque en fases posteriores del relato su relevancia se atenúa, su sombra permanece, sin embargo, latente en todo el texto. No era esta la primera vez que Candanedo se aproximaba a este asunto. Ya en Clandestinos, su primera novela ${ }^{9}$, la vía tenía cabida en la obra, aunque con un rol secundario y de menor carga simbólica. Los protagonistas, trabajadores inmigrantes explotados en la jungla del Darién, tratan con ahínco de llegar a la Zona para conseguir un contrato con los estadounidenses. Confían en que allí alcanzarán el ansiado bienestar. Para ellos, el canal es una suerte de utopía. No obstante, los veteranos en la selva han descubierto la verdad perversa del sistema laboral del que son presas. Saben que esas pobres víctimas no cumplirán ningún sueño. Terminarán tan alienados como ellos sin poder escapar del Darién: "Como nosotros, vienen todos con el pensamiento en el fondo del canal... A la Zona... ¡Buen canal van a tener también!"' (Candanedo, 1972, 14).

En La otra frontera, la vía adquiere una significación más amplia y se presenta desde una multiplicidad de perspectivas. Con todo, el tratamiento que le da el autor sigue la línea habitual en la época: "Hasta bien entrada la década de 1960, los intelectuales panameños asociaban el Canal de Panamá con la pérdida de la nacionalidad, la degradación moral, la prostitución, el colonialismo y el racismo" (Pulido Ritter, 2014, s/n). Muchos de estos tópicos están presentes en la propuesta de Candanedo. Por causa del paso marítimo, los campesinos de San Juan se ven abocados a una larga cadena de sufrimientos. El canal se juzga como el hito culminante que formaliza el dominio occidental del istmo. Desde el descubrimiento de la región y los primeros intentos de colonización, a finales del siglo XV y principios del siguiente, las potencias extranjeras, conscientes de las riquezas de la zona, habían acariciado la idea de controlarla para asegurar el flujo de bienes arrancados al continente y consolidar una óptima posición

9. Segundo premio en el Concurso Ricardo Miró de 1948 y publicada en 1957. 
geoestratégica en esa latitud. La región ha sido testigo por ello de un desfile grotesco de extranjeros que, con estos objetivos en mente, asaltaron el istmo sin miramientos.

El enemigo es poderoso y, por ello, recurrente. Los primeros fueron los españoles, con sus tempraneros planes para realizar el paso marítimo; al cabo les siguieron los corsarios y piratas ingleses. Durante la unión con Colombia, fueron, en una primera instancia, los estadounidenses — con el ferrocarril transoceánico - y luego los franceses — con la tentativa frustrada de canal- quienes trataron de domeñar a la indómita región. En todos estos acontecimientos poco importó el sufrimiento de los pobladores locales, que, como títeres de una fábula amarga, fueron manejados por unos y por otros sin voz ni voto. Finalmente, en época republicana, son los norteamericanos quienes han subyugado al altivo espíritu panameño. Por su poderío económico, tecnológico, organizativo y militar, su penetración se antoja más profunda. No en vano, ellos son los que han logrado terminar el paso. Sus intrusiones son de tal alcance que la nacionalidad corre el riesgo de perderse. Asimismo, los cuerpos de los individuos también están en peligro quedando al servicio de la potencia, que en pos de sus intereses los tritura.

Al pueblo el canal se le vendió por parte de las autoridades (en connivencia con los extranjeros) como progreso, sacrificio patriótico, fama y respeto ante el mundo. No obstante, la realidad es bien distinta. Las bondadosas intenciones pronto se abandonan y la administración estadounidense muestra su verdadera agenda: la expansión del libre mercado, la mejora de los transportes con fines comerciales y bélicos, el aprovechamiento masivo de la región y su apertura para la explotación por parte de las empresas de sus potentados. La vía, por tanto, no ha sido construida Pro Mundo Beneficio como se ha intentado hacer creer, sino para la rentabilidad de unos pocos, quienes lo manejan imponiendo sus condiciones.

El cuestionamiento del discurso triunfalista oficial sobrevuela por todo el relato y se resalta desde los paratextos que acompañan a la novela. Desde esta óptica deben entenderse las dos citas que, bajo el epígrafe "Simbolismo", anteceden la obra. La primera, no literal, sino actualizada al idioma contemporáneo, está extraída del capítulo CIV de la Historia general de las Indias de Francisco López de Gómara (1978, 157), mientras que la otra pertenece al ensayo de Eusebio Morales "El Tratado del Canal”, de 1904 (1928, 89). Primero, el cronista español, que nunca cruzó el Atlántico, manifiesta abiertamente el objetivo que perseguía Occidente desde el comienzo del proyecto canalero: la substracción de los recursos de los territorios absorbidos. Estas palabras, dirigidas de un vasallo a su rey, son entendidas por Candanedo como una evidencia transparente de que los occidentales, desde los primeros instantes, abordaron el istmo sin respeto cultural y con los intereses más espurios.

Por su parte, las declaraciones de Morales $^{10}$ son relevantes porque denuncian, en fecha bien temprana, el manejo egoísta de la Zona por parte de los aliados del norte. Su administración, a ojos del estadista, parece más centrada en propiciar el enriquecimiento de sus propios ciudadanos que en posibilitar un reparto equitativo de riquezas, lo cual obstaculiza el desarrollo del país en su conjunto, exigencia que los panameños demandaban a cambio de la entrega de una parte de su patria. A Candanedo, en línea con esa visión de la historia republicana, aunque medio siglo más tarde, no se le escapaba el valor profético del texto de Morales. Con los años, esa misma decepción fue calando en la nación en su conjunto ocasionando un gran malestar, pues se juzgaba que después del traumático proceso que hizo realidad la vía, para el pueblo solo hubo congoja, rapacería, maltrato y desarraigo: "Los barcos, el peaje, los millones... ¿y para nosotros qué?" - lamenta uno de los personajes_- "basuras" (43).

10. Eusebio A. Morales fue jefe del Partido Liberal y miembro de la cúpula secesionista que alcanzó la independencia en 1903. 
Ahora bien, la nación se hizo merecedora de ese castigo, pues perdió el camino recto sus valores - y cometió el pecado de caer rendida por la ilusión del dólar: "Dinero limpio... Todo es sucio. Ya nada hay limpio por él. Llega que destruye lo mejor del alma" (35). Por un momento, olvidó que el vil metal corrompe a los espíritus excelsos y ablanda a los trabajadores más capaces; que a los serios los vuelve irresponsables y a los austeros, disolutos. En ese instante, negó, ciega a las consecuencias, sus vínculos con la naturaleza y pasó por alto que, con la pecunia, se obtienen bienes materiales, pero que la libertad y el orgullo no se adquieren en los comisariatos ni en las cantinas. Desde este enfoque, el hundimiento de San Juan y el exilio de su comunidad se erigen como emblema de una patria castigada por sus desviaciones que debe luchar por restablecer su dignidad.

El dolor es grande; así lo muestran las reacciones de los campesinos al aceptar las retribuciones por sus tierras. Ningún precio puede paliar la pérdida de las raíces. Han quedado "sin tierra donde pisar, sin base, en el aire, rotos por dentro" (41). La depresión y la amargura azotan la aldea: los hombres, en el bar, calman el vacío bebiendo y las mujeres zurcen en la clausura de sus hogares silenciosos. El canal es una brecha en el propio territorio que ha permitido entrar al mar, "amargo, ilímite y siniestro" (34), hasta lo más íntimo, despojando de todo a la nación. Cuando el pequeño poblado es sepultado, se pierden las risas, los recuerdos, las horas de placer y hasta las tumbas de los antepasados. En definitiva, todo un fragmento de historia es lo que se esfuma. La humillación no puede ser más completa. Con la vía -lamenta uno de los personajes - , los panameños perdieron hasta "los pantalones [...], lo que más vale... Y no para la pérdida".

Como parte del inventario de agravios, el relato, asimismo, incluye un alegato ecológico en su examen de las secuelas causadas por la debacle canalera. No solo los humanos se vieron dañados. La naturaleza también pagó un alto precio para que se culminase el proyecto. Las junglas cayeron bajo la dictadura del machete, los ríos fueron domados por las presas y las montañas, cortadas como si fuesen poco más que nata. Como indica Castro $(2005$, s/n.), la construcción de la vía propició la devastación de paisajes enteros que habían desempeñado un rol central en la configuración de la identidad nacional. Un ejemplo de ello fue el asolamiento de una extensa sección del río Chagres, hasta ese momento una de las enseñas características de la naturaleza panameña. Célebre por el brío de sus aguas, su domesticación es un hito de las transformaciones ocasionadas por la modernidad en el istmo.

\section{Juan Cancio y la "hija" del Canal}

Una vez perdidas sus posesiones a causa del extranjero, a la comunidad de San Juan solo le queda el exilio en su propia tierra. Consternados, los que no se dispersan se marchan a parajes remotos siguiendo a Cancio, el nuevo guía. Se asientan en la provincia de Chiriquí, donde todavía no ha puesto sus garras el enemigo y que tan lejana parece de la Zona y sus negocios. La huida a esta región, colindante con Costa Rica, explica el título de la novela. La frontera por excelencia para los panameños es la que los separa de Colombia. Sin embargo, "la otra", al norte, siempre ha sido menos escuchada y cuidada por las autoridades estatales. Ese es, precisamente, el fin que persigue Candanedo, al que consagra tres tercios de la narración: dar a conocer y denunciar los padecimientos sufridos en esta remota parte del país, su región natal.

Con la decisión de marchar a Chiriquí, el joven guía cumple el mandato del maestro. "Lárgate para el occidente, que la vida apenas te comienza [...]. Sé que vales, que serás muy hombre... Serás mi sombra justiciera" (46). Por lo que pueda ocurrir, el heredero porta la escopeta que Cruz le entregó como último regaló. El viejo nunca se vio en la necesidad de usarla. Para Cancio los tiempos son otros, como le ha sido predicho. No obstante, si bien es tradicional 
la desprotección de los campesinos — demasiado ingenuos para presentar batalla-, esta vez tienen un líder.

No se equivoca el joven al traer el arma consigo, pues pronto se confirma lo peor. Panamá, cuyo canal la ha puesto en el mapa del capitalismo internacional, es el blanco de atención de multitud de inversionistas, que desean hacer negocios en el istmo. Se trata de la nueva moda en los mentideros de los economistas. Muchos de los emprendedores son estadounidenses, que buscan aprovecharse de las condiciones ventajosas y la protección que, desde la Zona, logra imponer, por los medios que sean, la administración de sus compatriotas. Las habilidades con la puntería del líder, adquiridas con la caza, su afición predilecta, pronto se verán a prueba.

Durante las partes segunda y tercera del relato, el lector asiste a un nuevo conflicto, surgido a consecuencia de la vía interoceánica. No en vano, se lo define como "la hija del Canal", ya que sin este no hubiera sido posible. Panamá, subordinada a la mayor potencia del continente desde su mismo establecimiento como república, ahora debe pagar la deuda por la ayuda recibida: es utilizada por sus verdaderos señores - sus captores - como un campo para expandir los mercados y fortalecer su presencia en el sur del continente. En esta nueva confrontación, los protagonistas deberán defenderse de la incursión de los terratenientes que, llegados a Chiriquí, buscan exprimir sus preciadas riquezas. De nuevo se repite el esquema: la paz local se cancela por la llegada de extranjeros.

Estos forasteros, frutos perfectos del engranaje que los ha forjado, vienen con experiencia de mando en otras latitudes centroamericanas, donde trabajaron para jefes más poderosos que ellos. Ahora, con un poco de fortuna acumulada, anhelan ser, por fin, los dueños. Durante ese tiempo en aquellos negocios, han aprendido los brutales modos con que tratar al obrero para maximizar los beneficios. Ese pasado allí les permite identificar las tretas de los empleados para robar tiempo y, gracias a esa época, son asimismo conscientes de las técnicas extorsivas que demanda la tozudez de un propietario local. Siempre hay alguno que se niega a vender sus dominios, necesarios para seguir expandiendo el proyecto empresarial, y hay que retorcerle la voluntad para persuadirlo.

Sin embargo, estos extraños saben cuidar las apariencias. Se presentan bien vestidos y con buen porte. Sus modales son exquisitos y hablan en perfecto español — otra más de las lecciones aprendidas. Cuando quieren algo son de lo más dulce ante los campesinos, que atónitos los contemplan en su ir y venir desaforado. Cuando abordan a los pobladores, en todo momento lo hacen con el dinero por delante. No les importa pagar, siempre que el precio lo pongan ellos. No obstante, su cólera es temible ante el menor contratiempo. Entonces, el torrente de amenazas se desata en sus bocas. Si estas no cosechan resultados, siempre dan un paso más. Por ejemplo, apareciendo fuertemente armados y con escolta —otros carroñeros despiadados como ellospara amedrentar a la víctima.

Paralelamente, son expertos en pleitear en los tribunales y en conseguir lo que desean de jueces y autoridades. Estos tampoco se hacen mucho de rogar, pues ven favorablemente la reducida porción de beneficios que les toca. En su papel de intermediarios entre terratenientes y campesinos, los representantes del Estado suelen decantarse indefectiblemente por el lado del poder: "La ley en malas manos resulta siempre despiadada y sin corazón" (107). Subyugando y retorciendo la justicia a golpe de sobornos y favores, los latifundistas norteamericanos consiguen vía libre para sus planes de explotación agropecuaria.

Estos terratenientes conocen bien el entorno istmeño en que se desenvuelven. Analizando las anquilosadas estructuras de la sociedad local han detectado una fisura por la que pueden, mediante mecanismos legales, asentarse en la región. Grandes extensiones de tierra están en 
manos de la clase alta, pero esta, aferrada a la irresponsabilidad de una vida disoluta, se ha degenerado y ha perdido buena parte de su bienestar económico. Formados en el extranjero, no son más que señores que viven de las rentas y que gradualmente van ocupando los puestos elevados en la gestión del Estado, los que previamente habían desempeñado sus antepasados. Necesitan efectivo, así que se deshacen de grandes porciones de sus haciendas, que compran los extranjeros, con los que forman una alianza entreguista y traicionera.

Sin embargo, el ansia por acaparar recursos es una sed que difícilmente puede calmarse. Los norteamericanos pronto desean ampliar sus linderos, haciéndose con las tierras de los pequeños propietarios cercanos. Aquí llega el impulso que provoca nuevos movimientos en el mecanismo de la trama. Dos concepciones extremadamente adversas de la vida y el planeta vuelven a impactar, revitalizando el conflicto insoluble. Unos, representantes de un entendimiento humano del trabajo, basado en extraer de la naturaleza lo necesario, se caracterizan por su honestidad y cultura simple, pero profunda. Encarnan lo estable, lo que no muta, pero que a la vez produce serenidad en el espíritu. Por su parte, el polo de los terratenientes viene cargado de significaciones negativas. Ellos son sinónimo de producción, devastación, crueldad y necesidades de mercado. Con su venida, llega el frenesí, el ruido y el vértigo. Padecen de una única enfermedad: el afán por acumular riqueza. En esto no se diferencian de sus antecesores: todos los extranjeros que cabalgaron por el istmo con esa misma meta. Su presencia trastorna la marcha del orden cotidiano: todo es incertidumbre para quienes intentan sobrevivir a su vera.

Las diferencias de temperamento también se remarcan en el plano físico. En el relato, los occidentales son altos, rubios, de tez blanca y ojos azules, mientras que los latinos son morenos de piel oscura. Los primeros se sienten superiores. No por nada, su raza ha sido la que ha logrado la construcción del canal, piensan. A su entender, los latinos son débiles, escuálidos, sin valor y, por supuesto, incapaces de gobernarse con sensatez. Amparándose en lo que para ellos son grandes - aunque en realidad ligeras - desemejanzas, justifican su racismo. La novela proyecta así una realidad puesta de manifiesto por la historiografía (Araúz, 2013, s/n.). Los estadounidenses que se trasladaron al istmo en conexión con el fenómeno canalero procedían mayormente de las regiones del sur de su país, donde las políticas segregadoras se habían mantenido vigentes durante decenios. Sus comportamientos en Centroamérica suponen una continuación de prácticas muy arraigadas en ellos. De hecho, en la obra a los terratenientes se les conoce como los "sureños" (103). Sin embargo, tras esta animadversión, lo que de verdad se oculta es un fenómeno más siniestro. No estamos ante una pulsión emocional únicamente enraizada en tradiciones añejas, sino que detrás se oculta una pretensión de mayor calado: "La construcción de grupos étnicos como parte del proceso de organización y control de la fuerza de trabajo [...] por parte de la potencia colonial" (Castro, 2005, s/n.). De este modo, se normaliza que los trabajos más ingratos sean para quienes tienen la piel más oscura y que se emplee la violencia contra unos seres supuestamente degradados, pero a los que en verdad se les busca exprimir hasta quebrarlos.

Asimismo, además de traer consigo mentalidad y hábitos racistas, los estadounidenses arriban al istmo con una visión reduccionista y tópica de la realidad local. Como Castro (2005, s/n.) señala, Panamá fue entendida en el imaginario norteamericano como un lugar no sujeto a los estándares de la cultura occidental en el que poder actuar a capricho. Tenían en sus manos una región pendiente de ser capitalizada. El país, a sus ojos, no era más que una zona salvaje a la que civilizar y a la que salvar de su propio primitivismo. Es por ello que, en la narración, no faltan los planes para asfaltar carreteras, ni los proyectos para desarrollar sistemas de irrigación ni las aspiraciones de aplicar actualizados mecanismos de siembra y cosecha. Lo que se pretende, en el fondo, es conectar a la atrasada región con las rutas del capital mundial y de impulsarla al siglo XX desde su miserable cotidianidad rural y precapitalista: "Hay que curar a 
estos pueblos de su salvajismo español-indígena: la ineptitud, la anarquía y la pereza" (89) señala míster Palmer, el más dañino de estos invasores - y hacerlos producir. Las graves dificultades para poner en marcha un sistema industrial a la manera occidental en el trópico, a más de 6500 kilómetros de Washington, pusieron a prueba el brazo estadounidense, que desarrolló toda una cultura adversa a la vida natural de la región istmeña, a la que juzgaba, como señaló Paul Sutter (1997, s/n.), de espaldas al progreso, y, por supuesto, contraria al carácter de sus gentes, problemas ambos que habían de eliminarse si se quería el éxito. Se autoimpusieron así la tarea de "enseñarles el respeto a la propiedad, al trabajo [...], a lavarse" (89) a los locales.

La clase alta panameña compra el mensaje civilizatorio y deja hacer y deshacer a los extranjeros con total libertad. Las élites criollas, con intereses y conexiones con el comercio mundial, se dejan persuadir por esa nueva promesa de fortuna. Por esta razón sienten la necesidad de participar en ese combate contra el salvajismo que denuncian los representantes del norte. De este modo, buscan desarrollar el sector económico y crean leyes que facilitan el acomodo de inversores foráneos, poniendo a disposición de estos cuales medios requieran; incluso el propio suelo si lo demandan. Más importante aún, difunden entre la población el mensaje de que este proceder es desinteresado.

Esos intentos solo se ven obstaculizados por los propietarios locales, quienes perciben la verdad detrás de los filantrópicos planes para la provincia. Ellos se postulan como los auténticos defensores de la patria y no pierden de vista que, aun cuando vengan disfrazados de buenas intenciones, los potentados solo buscan su medro personal. La solidaridad y bondad de sus aspiraciones civilizatorias únicamente esconden maldad, avaricia y opresión. Sus modos no respetan la cultura del territorio al que han arribado, a la que no conceden el menor valor: "A donde llegan ellos arrasan con todo... Nada queda en pie, nada nos dejan, para imponer y alzar lo de ellos, para que eso valga... Que de nosotros no queden ni señales... [...] Después podrán decir: "eran salvajes... no había nada" (41). Esta acción destructiva de los supuestos agentes civilizatorios indigna a los pobladores. Ante estas resistencias, los estadounidenses se muestran inflexibles: "Estos pueblos no se dejan civilizar... Nunca están conformes. Otro sería el signo de Centro América [sic.] sin ese crimen indígena" (89). En su incomprensión, creen que todo el país alberga un resentimiento profundo y que el panameño aprecia muy poco todo lo que se está haciendo por él.

La falta de sensibilidad ante lo que se concibe como demandas ilegítimas de quienes no deberían ser más que subalternos, conduce a los norteamericanos a la desconfianza y al miedo. El terrateniente, aunque vive rodeado de goces, no descansa: una psicosis desasosegante lo mantiene alerta frente a unos locales a quienes concibe como un peligro latente, siempre a la espera de desatarse. En cualquier momento se puede caer víctima del asalto, la estafa o el asesinato: "Véanles los rostros: el delito se les descubre a simple vista, criminales es lo que produce esta tierra" (109).

Ese terror subyace en la severidad y el maltrato hacia los empleados. Los capataces muchos de ellos hispanos - son instruidos en la aplicación de los castigos más duros —incluidos los físicos - ante los menores agravios. Debe mantenerse a raya a los díscolos. Los encargados, soñando ser ellos ricos jefes algún día, satisfacen los requerimientos de los dirigentes. Su codicia y ambición conocen bien el camino al ascenso: la obediencia, el seguimiento férreo de las normas y la brutalidad como vía para maximizar los beneficios. Ser, en definitiva, un tirano para sus propios semejantes: esa es la manera de ganarse el beneplácito de los superiores. Así llegan los lujos, las vacaciones pagadas y los estudios de los hijos en Estados Unidos. La represalia favorita: rebajar el sueldo ante la más leve falta. Saben que beneficiar a la empresa es mirar por uno mismo. 
Los locales -empleados o vecinos de los terratenientes y sus secuaces - son quienes ocupan la posición más vulnerable, constantemente avasallados por el empuje de las fuerzas del mal. Humillados, golpeados e, incluso, asesinados, son víctimas a las que se les aplica un régimen de violencia desmedido. Cuando uno de ellos fallece en extrañas circunstancias, nadie investiga seriamente. Es justo lo contrario a lo que ocurre cuando muere un blanco, aunque sea célebre por su mal proceder. Se llevan a cabo múltiples pesquisas, se promociona en los medios y se comenta en las esquinas. Rápidamente se buscan culpables, aunque la precipitación incurra a veces en la calumnia de inocentes. Cuando un local es acusado por los poderosos de algún crimen - injustificadamente, en la mayoría de ocasiones que presenta la novela -, se pide para él la pena capital. Los terratenientes, contrariando la ley, se atreven a solicitar incluso el traslado de panameños a la Zona para que sean juzgados por delitos cometidos en territorio bajo soberanía nacional.

En la conflagración dispar entre estos David y Goliat modernos, no pasa desapercibida una línea discursiva de las relevantes en la novela: el cuestionamiento y refutación del tópico de civilización y barbarie como vía para superar el atraso en América. Como es ampliamente sabido, esta narrativa sobre la realidad argentina y, por extensión, de toda la América hispana tiene su origen en Facundo o civilización y barbarie en las pampas argentinas (1845) de Domingo Faustino Sarmiento. Esta visión liberal sobre el estado del continente alcanzó un éxito notable durante buena parte del siglo XIX, pues legitimaba la acumulación del poder en las distintas burguesías de cada república, a las que debían desarrollar siguiendo patrones occidentales. Junto con la implantación de la democracia y el libre mercado, el fortalecimiento de la industria, la mejora del transporte y el establecimiento de conexiones firmes con el mundo avanzado, se identifica la formación educativa como la clave para abstraer a la población del oscurantismo: "El nuevo gobierno organizará la educación pública en toda la República con rentas adecuadas y con ministerio especial como en Europa, como en Chile, Bolivia y todos los países civilizados; porque el saber es riqueza, y un pueblo que vegeta en la ignorancia es pobre y bárbaro" (Sarmiento, 1874, 171). Centrándose en los gauchos, a los que define como seres esenciales con potencial para ser ciudadanos, Sarmiento defiende, en definitiva, la europeización del continente como camino para alcanzar el bienestar. Aquellos elementos no afines con el modelo propuesto deberán ser domesticados e insertos en el sistema capitalista.

Ahora bien, como destaca La otra frontera, este ideal, tan sensato en superficie, conlleva una aniquilación, un exterminio, pues América debe abandonar, en parte, su ser. El progreso conlleva la pérdida de la vida natural, inocente, de siempre, modos más humanos y en armonía con el planeta que el trastorno en que los occidentales viven inmersos. Entonces, ¿quiénes son los bárbaros? ¿Quiénes, los civilizados? No puede olvidarse que, bajo el aura de estos planes de desarrollo, se erradicó a multitud de comunidades nativas en la Argentina de fines del XIX. Su crimen: no plegarse a los dictados de la modernidad.

Ante eso, el relato de Candanedo expone que este terremoto desarrollista arrasa, sin justificación válida, con los pueblos, quienes deben luchar por lo suyo, tan válido como lo de otros. Frente al poder de Calibán, Ariel se alza, guiado por la nobleza de su espíritu. En la novela, el cuestionamiento al catastrófico progreso que viene de Occidente se refuerza desde un convencimiento arielista. "Veremos quién vence, si su alma, su espírrituuu [sic.] o mi poder, fuerte y saludable, mis dólares" (37), le escupe en la cara a Cruz el anglosajón que desea comprar sus tierras al comienzo del relato: el enfrentamiento entre el ideal y el materialismo no puede quedar mejor reflejado, choque que determina transversalmente la obra en todos sus niveles de significación.

José Enrique Rodó fue quien expuso por primera vez esta manera de entender las diferencias entre los americanos del norte y del sur. En su célebre Ariel (1900) concibió la 
identidad nacional tomando como base algunas divergencias dicotómicas entre Latinoamérica y los Estados Unidos. Lo que más resaltó fue el idealismo de los primeros frente al utilitarismo de los segundos. Su propuesta tuvo una influencia clave en el pensamiento latinoamericano y, en concreto en Panamá, al que marcó profundamente (Ibáñez, 2018, 66 y ss.). A través de ella se expresaba vehementemente un amplio sector de la intelectualidad burguesa de comienzos del siglo XX:

Que políticamente puede fijarse entre la efectividad de los regímenes constitucionales elitistas de la primera mitad del siglo, con sus prácticas de participación limitada y condicionada por sólidas jerarquías sociales y culturales, y el advenimiento de las democracias de masa o de sus variantes bonapartistas, crecientemente basadas en grandes organizaciones burocrático-estatales o burocráticopartidarias (Real de Azúa, 1976, XV).

Como indica Real de Azúa en su prólogo a Ariel, es esta una época cumbre del capitalismo, en la que se lucha por los territorios coloniales. También es este un periodo en que la sociedad de masas y las exigencias de bienestar comienzan a tomar forma intensamente: "La sociedad industrial estaba en plena marcha hacia su posterior madurez, las clases medias insurgían hacia la dirección o, por lo menos, hacia la plena audiencia, el proletariado se organizaba políticamente y el poder del dinero procedía a unificar y reificar todas las valoraciones sociales" (Real de Azúa, 1976, XV). Finalmente, los objetivos de la modernidad, entre los que cabe destacar la consolidación de la ciencia, la razón, el progreso y la libertad, permiten entrever otra faceta, la de una sociedad homogénea, deshumanizada y vulgar (Real de Azúa, 1976, XVI). En este marco Ariel supone un llamado nacionalista a las juventudes cultas del continente.

Rodó (1976) enfrenta los fundamentos de la cultura basada en la espiritualidad de Hispanoamérica a la mediocre inclinación estadounidense por lo material. Los orígenes de dicha cultura idealista se remontan a la tradición grecolatina, al hispanismo y a la religión católica, los cimientos para el establecimiento de una sociedad democrática que habrá de quedar bajo la dirección de sus miembros más capaces. El liderazgo intelectual del subcontinente tiene la misión de conformar un Estado basado en un ideal universal de democracia, libertad y justicia. A la esencia espiritual y candorosa de Ariel se enfrenta su reverso, Calibán, prosaico, salvaje y materialista. Con estos arquetipos shakesperianos, Rodó expone la profunda desemejanza entre el ser y el proyecto latinoamericano y el estadounidense.

Justamente en Panamá, el pensamiento arielista encajaba a la perfección, pues el enfrentamiento entre un modelo y otro se palpaba como una realidad física dolorosa. La dirigencia nacionalista pronto lo hizo suyo. Belisario Porras — varias veces presidente de la República-, en una "Carta" a sus seguidores del 24 de abril de 1904, es el primero en expresarlo más o menos claramente: "Me ha inspirado siempre un gran temor la ayuda del poderoso al débil, porque es protección que esclaviza y, sin que pueda remediarlo, es más fuerte que mi voluntad la idea de que existen en perspectiva próxima no lejana y más o menos disfrazadas, la absorción y la conquista". (Citado en Isaza Calderón, 1994, 421). Como ha destacado Ritter $(2007,10)$, este texto expone "una crítica antimoderna de la modernidad en el país", pues no juzga positivas las influencias foráneas que llegaban a tierras panameñas. Con el pasar de las décadas, la permanencia de lo extranjero en suelo propio estimula una retracción hacia el idioma, la cultura y la religión tradicionales, así como una valoración positiva de la agricultura y de la industria. A ellas, se contraponen el mercadeo y las ocupaciones vinculadas con el canal, concebidas como ajenas e inicuas.

Sin embargo, Candanedo se distancia del arielismo más clásico y propone que el liderazgo de la comunidad no debe recaer en la cúpula intelectual, sino en los más honrados, viriles y esforzados de quienes pertenecen a la patria. Estos valores son los que encarna Cancio y 
todos los que se unen a él. La cultura libresca — parece desprenderse del relato - no asegura la bondad de los individuos y, además, resulta, por débil, inadecuada para la indómita región istmeña.

Después de algunos años (1912-1919) de buenas cosechas en el norte del país, al grupo del discípulo de Cruz le va bien. Se han escuchado rumores inquietantes de extranjeros transitando por la región, pero nada preocupante. Hasta que un día Cancio ve a un forastero: “¡Calamidad! ¡Desgracia! También extraños... Ya tienes trabajo otra vez” (124). Su maestro, además, se le presenta en sueños alertándole, por lo que no puede desoír el mandato. Su primera reacción es armarse con la escopeta y empezar la "merma", el asesinato selectivo de los extranjeros uno a uno hasta que, desmoralizados, abandonen la región. Hostigarlos hasta que la vida les resulte insufrible. Cancio no va a entregar esas tierras, que son tan fecundas. En realidad, la pulsión que lo induce a luchar es constatar, de nuevo, las negativas transformaciones que los extranjeros siempre causan allá por donde pasan. Recabada información, el joven descubre que la virginal tierra a la que llegó años atrás es ahora un infierno por culpa de ellos. La confirmación de esta realidad le lleva a retomar su conciencia y a saltar a la acción. En este punto Cancio inicia su aprendizaje como guerrillero, experiencia que le mejora como líder y le prepara para futuros peligros.

Las extorsiones de los terratenientes van en ascenso y generan un malsano ambiente de crispación. Como respuesta, se desatan las reacciones airadas de la población, que aumentan en dureza. Empiezan a producirse muertes sospechosas, todas ellas de extranjeros con un largo historial como abusadores. Ante la inquietud de que los locales se rebelen definitivamente, los estadounidenses solicitan a la Zona el envío de un contingente militar que ponga paz y rebaje la tensión. Si bien hay un forcejeo entre autoridades panameñas y norteamericanas - estos no deberían poder mandar tropas a su antojo por el territorio nacional-, al final los terratenientes acaban imponiendo su voluntad a base de dólares y amenazas: ciento treinta unidades se despliegan en la provincia de Chiriquí. Candanedo recoge aquí un episodio real: el envío de tropas desde la Zona que se produjo en 1918 para proteger las fincas que abastecían de alimento los comisariatos, mantenidas en la región hasta 1920 (Pizzurno y Araúz, 1996, 119).

La llegada de los militares no mejora, como era de esperar, la situación de los campesinos, más bien todo lo contrario. En cuanto arriba el destacamento, los efectivos adoptan una actitud de agresión y se comportan de facto como una guardia pretoriana de los potentados estadounidenses. Comienzan los toques de queda, las detenciones arbitrarias y las expulsiones forzosas de pequeños propietarios, así como las violaciones de mujeres, los disparos contra quienes incumplen las normas y la quema de hogares con sus moradores -indígenas - dentro. La turbación y el crimen se instalan en el día a día de los desprotegidos habitantes de la provincia. Cualquiera puede ser la siguiente víctima de los uniformados.

Cancio encuentra en el asesinato selectivo de estos soldados el objetivo ideal para su estrategia de hostilización. En su pelea por dar caza a sus oponentes, se gana el sobrenombre de la "Sombra", como apodaban a Cruz. Se enfrenta, emboscado, a los peligros de la selva, y mata. Sufre persecución y es víctima de tiroteos. Llega a ser, incluso, detenido por los soldados, que lo quieren mandar directamente a la horca, pero logra escapar, demostrando su astucia. Con la información obtenida durante su captura, refina su venganza.

Este tiempo le convierte en soldado. Capaz de diseñar inteligentes estrategias, se gana el respeto de su comunidad mediante las palabras, que domina mejor que Cruz, aunque es callado, y sus actos de valentía. En uno de sus lances, al inicio de la campaña contra la "hija del Canal", recibe un balazo en la cabeza, que le deja un rasguño. Es su bautismo de fuego: la señal de que ha sido tan hombre como para enfrentar el combate y sobrevivir. Esa cicatriz perpetua en su 
frente es la marca que le distingue como único: el elegido para mandar, el guerrero auténtico capaz de desafiar a la muerte sin dudarlo.

Pasados los meses y tras dejar un rosario de cadáveres, el conflicto llega a término. Los soldados no pueden soportar las bajas causadas por el escurridizo enemigo. La moral ha decaído y la tropa, más preocupada por salvar su propio pellejo, ya no le ve sentido a seguir con la caza. Deciden retirarse, dejando a los terratenientes sin parapeto, los cuales, entendiendo que el negocio se torna complicado, también optan por marcharse. Cancio, por su parte, proclama que esta liberación es un triunfo de Cruz, el inspirador, quien plantó en el nuevo líder la semilla de la resistencia: "Si el chico de peso y tamaño usa cabeza y malicia, le puede al de fuerza y medio tontón” (76). Así deberá proceder Panamá ante el descomunal enemigo.

\section{El "otro Canal" y el triunfo de la lucha colectiva}

Como ha señalado Isis Tejeira $(2007,13)$, la realización de la vía interoceánica no se llevó a término únicamente por el rol que desempeñó Estados Unidos con su tecnología puntera y enormes recursos, sino porque la nación panameña entregó una extensa porción de su territorio para que el sistema económico y comercial de Occidente consolidara un avance clave, el que ha facilitado numerosas mejoras para el mercado entre las naciones, determinado hasta ahora por el dominio hegemónico norteamericano.

Sin embargo, los panameños juzgaron que la única retribución que se les había concedido fue el asedio de la identidad propia por elementos foráneos, la incapacidad de afianzar su auténtico carácter nacional — digno de una organización estatal-, la intervención en sus políticas sociales y económicas, la torsión de su verdadero desarrollo histórico y el desgaste de su autoapreciación. Todas estas operaciones del capital internacional en suelo istmeño causaron tal efecto que, para Tejeira $(2007,13)$, la realización de la vía interoceánica supone para el país "la negación de su identidad, la negación de su personalidad como nación, la negación de su historia y el deterioro de su autoestima hasta niveles alarmantes". La incursión estadounidense, con la puesta en marcha del canal y las sucesivas iniciativas privadas que le siguieron, normaliza un estado de incertidumbre, confusión y pérdida entre la población local, que ve su identidad quebrada y subyugada a intereses crematísticos que arrasan con buena parte de sus costumbres, tradiciones y valores. De hecho, uno de los rasgos típicos de la novela canalera es la descripción de la población local hundida y desolada.

Esta crisis, vista como fundamental para la nación, provoca que la comunidad panameña configure un retrato de sí misma determinado por el que le imputa la narrativa neocolonial, que se apoya en desarrollar sentimientos de inferioridad y sumisión, en la subalternidad y en la imposibilidad para decidir y construir el propio porvenir. Esta idiosincrasia estimula en el colectivo social al completo una impresión de desaliento y pesimismo heredado por generaciones, que ha obstaculizado frecuentemente la asunción y el desenvolvimiento de una vigorosa conciencia de identificación nacional (Castro, 2005, s/n.). La otra frontera se levanta contra esa narrativa y propone una redención heroica para Panamá ganada por la sangre.

En la última parte del relato, un nuevo enemigo se hace presente. En este caso, obedeciendo a una gradación ascendente que incrementa la tensión, se trata del más peligroso de ellos: la Compañía, que, dedicada a la explotación del banano, esclaviza a sus trabajadores y provoca de nuevo grandes modificaciones en el paisaje natural panameño. Este es el "otro Canal": un nuevo capítulo de miserias y sufrimiento se inaugura para los pobladores locales, pero también de esperanza y realización. Es como si Candanedo pareciera transmitir que para superar la crisis de autoestima hacen falta victorias, y estas solo se consiguen combatiendo. Los 
protagonistas encontrarán la salvación con las armas en la mano, una clara invitación a los lectores panameños, a quienes se dirige la obra.

La corriente narrativa que se ocupa de las plantaciones bananeras y del mundo de relaciones surgido en ese particular espacio tuvo un amplio desarrollo en Centroamérica durante las décadas centrales del siglo pasado. Esta tendencia recogía los enfrentamientos entre grandes empresas transnacionales dedicadas a la explotación agrícola — en muchas ocasiones formando tándem junto a sus aliados, las corruptas autoridades locales - contra los peones rurales dependientes de estas compañías. Estos se ven envueltos en una lucha por el reconocimiento de derechos básicos vitales como la protección de su salud en el lugar de trabajo o la dignidad de los salarios. No obstante, detrás de estas exigencias suelen hallarse otras de mayor calado: la liberación del país de los agentes del imperialismo capitalista occidental, el establecimiento de un sistema sociopolítico y económico más justo y el fortalecimiento de la identidad nacional.

Mamita Yunai (1941), del costarricense Carlos Fallas, ha sido considerada por la crítica como la novela paradigmática de este subgénero, aunque precede a una tradición en la que destacan, por ejemplo, Sangre en el trópico (1930) de Hernán Robleto, nicaragüense, o Bananos y hombres (1930), de la también costarricense Carmen Lyra (Grinberg y Mackenbach, 2006, 161). Este ciclo entronca, en plano continental, con el movimiento regionalista que, desde la segunda década de la centuria, llevaba denunciando las grandes problemáticas que afectaban a amplias masas de población en Latinoamérica (Grinberg y Mackenbach, 2006, 162).

Candanedo, con La otra frontera, realiza su aportación a la corriente, que, aunque tardía, no deja de ser valiosa por original en el medio. Como señala Pérez Venero, "cuando Candanedo escribe sobre la explotación que perpetúan las compañías bananeras, el autor utiliza un área de la literatura no muy común en Panamá" (Pérez-Venero, 1978, 51). Pocas obras del repertorio nacional se han acercado a esta realidad. Flor de banana (noche de fruta) de 1970, firmada por Joaquín Beleño, sería el otro título relevante del ciclo en Panamá.

Sin embargo, la United Fruit Company - la trasnacional auténtica a la que se enmarcara en la obra con el nombre de la "Compañía"- operó en suelo nacional desde fecha muy temprana, 1900. La empresa había sido fundada en 189911. Desde Costa Rica, donde se creó, se expandió después a Panamá y, progresivamente, a buena parte de Centroamérica y la costa colombiana (Pereira Burgos, 1974, 77). Su quehacer se centró en la explotación masiva del terreno, al cual sangraba para que produjese fruta que introducía en Estados Unidos, de cuya influencia en la región la United se aprovechó en multitud de ocasiones. Su actividad también se caracterizó por el desarrollo de infraestructuras, transportes y comunicaciones que, de nuevo, ocasionaban una abrumadora modificación de los paisajes, y una falta de integración real en las economías locales. Pocos beneficios quedaban para los trabajadores y, en general, para las frágiles sociedades caribeñas y centroamericanas derivados de sus operaciones. El consorcio apenas fue forzado, durante la primera mitad del siglo, a pagar impuestos gracias a las enormes concesiones obtenidas de las burguesías dirigentes de cada una de las repúblicas.

Como suele reflejarse en las producciones del subgénero, la vida para quienes se veían en situación de vender su fuerza laboral a tales jefes era, en general, ardua y precaria. La mortandad en las plantaciones era frecuente a causa, entre otros factores, de la malaria, las picaduras de alimañas y el uso de pesticidas venenosos. En el plano real, la penosa condición en que se encontraban llevó a muchos de estos peones a concienciarse de la necesidad de un cambio y a organizarse para protestar. Valga como ejemplo la huelga bananera de 1934 en Costa Rica, en la que actuó como líder el mismísimo Fallas. Paulatinamente, las sucesivas victorias proletarias han asegurado, con el pasar de las décadas, un mayor nivel de bienestar para estos trabajadores y sus

11. Resultado de la unión de las compañías de Minor Cooper Keith y Andrew Preston. 
países. Se aumentó la carga impositiva a la transnacional y se incentivó la aparición de productores locales, lo que enriqueció a las sociedades desde dentro. Con todo, la United Fruit Company sigue operativa aún hoy bajo el nombre de Chiquita y ocupando un puesto relevante en el sector de la exportación frutícola ${ }^{12}$.

En 1926 la United decide trasladar sus operaciones a Chiriquí, en la costa del Pacífico. La base originaria en Bocas del Toro había atravesado un periodo de dificultades a causa del hongo llamado "Mal de Panamá" y del agotamiento de las tierras (Arosemena, 1973-1974, 6 y ss.). Por los indicadores que ofrece el texto de Candanedo, podemos deducir que ese es el momento histórico en que Cancio y sus seguidores hacen frente a la Compañía. Aunque el autor se traslada en su relato unas décadas atrás, la problemática seguía estando vigente para el momento en que redactaba su obra. De hecho, en 1950, la United reanudó con gran éxito la producción de banano - esta vez un nuevo tipo, resistente al "Mal"- en Bocas del Toro (Pereira Burgos, 1974, 78-79). Asimismo, en 1952 se produjo en Panamá la intentona de una gran huelga, sofocada en conjunto por la empresa, los esquiroles y las autoridades (Pereira Burgos, 1974, 80). Finalmente, en 1960, la United hizo cambios en el pago de las horas de trabajo complementario, lo que llevó a la indignación y al levantamiento de los trabajadores en las plantaciones de la costa atlántica. Candanedo, al tratar el pasado, está ocupándose de su realidad, explicando las raíces de la problemática, nacida también del seno del canal.

Esta última parte de la narración reproduce, por tercera vez, muchos de los tópicos que ya han aparecido. En cierta forma, todas las coordenadas ideológicas que han ido sobresaliendo a lo largo de la trama confluyen en este punto amplificadas para dar lugar al intenso desenlace. De nuevo, la situación idílica se quiebra con la llegada de extranjeros, que vienen a estudiar y medir las condiciones de los terrenos. Su sola visión causa el pavor de los pobladores, que ya han vivido experiencias similares. Al poco, se inician los acercamientos de los agentes del capital para que los propietarios se desprendan de sus parcelas por un precio conveniente. También se inician la violencia, las amenazas y la extorsión hacia quienes se niegan a vender.

Una vez conseguida una gran extensión fértil, comienzan los trabajos de adecuación y el desarrollo de infraestructuras. Otra vez, vuelve a ponerse de manifiesto que, aunque la operación se revista de civilización y progreso, no es más que la obra de la barbarie encarnada por los ávidos occidentales: "Campanas de gloria... loas al progreso paradisiaco... himnos a la prosperidad a raudales... pero, en realidad, infamia" (146).

Igualmente, en esta parte vuelve a activarse la carga ecologista que transmite la obra. A causa de las labores para levantar las instalaciones de la empresa, la selva sufre, como en anteriores ocasiones, una gran devastación, una pérdida que poco importa a los responsables de la Compañía. Arrasan con flora y fauna para plantar sus bananos, lo único que les obsesiona. En la manera de acercarse a la naturaleza, vuelve a subrayarse la enorme distancia que separa en la obra a panameños y estadounidenses.

En poco tiempo, los parajes vírgenes van siendo sustituidos por líneas férreas, estaciones, puentes, sistemas de irrigación y almacenes. También, se llevan de los planos a la realidad las oficinas, talleres y hospitales; hasta un campo de béisbol se proyecta para deleite de los empleados de mayor rango. Por supuesto, no faltan los comisariatos, propiedad de la Compañía, donde los empleados retornarán su sueldo al abastecerse de bienes de consumo diario a precios elevados. Toda la belleza de la creación destruida por la frivolidad de unos hombres equivocados parece sugerir, sin embargo, el relato. El escenario queda - para tranquilidad de los biempensantes - ordenado, medido y recortado.

12. Para más información a este respecto se recomienda acudir a la página web de la United Fruit Historical Society: http://www.unitedfruit.org/ 
Al costado de las instalaciones del emporio, se levanta un poblado, gris y miserable, de casas de chapa para los trabajadores y barracas para los indios, que la empresa va a enrolar en masa por su bajo coste y docilidad. Allí todo está dispuesto para que el obrero caiga en una trampa de la que es imposible escapar: "la suciez [sic.], la imprevisión, las cantinas y prostíbulos actuando como trapiche siniestro operado por un festivo Satanás, molerían al inocente para extraerle los líquidos aprovechables [...] y luego llevarlos al mercado" (147-148). En esa vida deprimente, el sueldo se malgastará a la búsqueda de placeres efímeros con los que paliar momentáneamente el vacío. De nuevo, la novela resalta los perjuicios del ocio y la prostitución. Una semana después del día de pago, muchos empleados sufren de enfermedades venéreas.

Una vez bien asentada y pertrechada, la Compañía inicia la verdadera actividad laboral. El mundo de relaciones que se establece entre empleadores, capataces y operarios destaca por su violencia y perversidad. Los trabajadores son engañados en el sueldo y no se respetan ni las vacaciones ni la jornada de ocho horas. Si hay enfermedad, se minimiza para no conceder baja. De nuevo, las faltas leves son purgadas con castigos desmesurados. Nadie puede protestar, ya que ganarse la fama de tipo conflictivo es lo peor que le puede pasar a un obrero. Si se incluye a alguien en la lista negra, no volverá a tener trabajo. El mundo de la plantación sufre tal perturbación que el color verde, en él, ha dejado de ser sinónimo de esperanza para significar muerte.

La Compañía importa un modo de entender el trabajo en el que solo es relevante la ganancia, sin escrúpulos. Todo detalle está pensado para obtener la máxima rentabilidad. Los trabajadores locales que hacen suya esta mentalidad caen en la desgracia. Los dirigentes ya lo tienen todo calculado para que la riqueza no filtre en exceso hacia las capas inferiores: "Todo movimiento debe rendir ganancias, siempre ganancias, muchas ganancias para muy pocos... y pérdidas, siempre pérdidas para muchos (151). Incluso, lo que a primera vista parecen beneficios, es en realidad una tortura: sus cuerpos quedan al poco masacrados por la maquinaria de la transnacional. Vuelve a reproducirse la misma tragedia que en los tiempos del Canal, de ahí el paralelismo que establece la novela entre una y otra empresa: miles de seres humanos, aspirando alcanzar una vida mejor, llegan al istmo desde todo el mundo atraídos por las promesas de dinero fácil. Sin embargo, su proyecto de liberación por la vía capitalista solo resulta en explotación y miseria existencial, lo que conduce a una anulación de sí mismos: "La Compañía no quiere gente que le trabaje sino esclavos que le entreguen la última gota" (166). Como marionetas que el capital maneja a su gusto, olvidan hasta su historia, identidad y destino.

No obstante, de vez en cuando se producen altercados. Los abusos de los capataces al aplicar el reglamento tendenciosamente despiertan la ira de los trabajadores. Estos, en un arrebato de rabia, queman alguna finca o linchan a algún encargado de mala fama. Las represalias de la Compañía son siempre desmesuradas. Se dispara por la espalda al infractor que huye.

La rebeldía de los panameños provoca que los gerentes de la empresa pongan sus ojos en los nativos de las montañas. Con promesas falsas y adulación, consiguen el apoyo de los caciques locales —en su mayoría, guaymíes-, que respaldan a la empresa, lo que provoca el traslado masivo de indígenas a las plantaciones. Allí se ocupan de las tareas más arduas y dañinas por bajos salarios. Muchos de ellos no volverán.

No obstante el tratamiento de denuncia con que se tematiza la cuestión del indio, cabe señalar que este es uno de los puntos débiles de la obra, entendida como artilugio de concepción progresista. Al guaimí se le dibuja sin rasgos culturales, sin valores sólidos, casi carente de intelecto. Sin personalidad, es poco más que un trozo de carne que, como veleta, se mueve en la dirección en la que lo impulsan. En su ignorancia se abraza a los árboles, a los que salva con los 
pesticidas, sin percatarse de que al mismo tiempo se está matando a sí mismo. La propuesta de Candanedo es, por tanto, bastante pobre a la hora de representar la alteridad. Ya destacamos la sorprendente ausencia del antillano; a ello se suma ahora la deslucida descripción de los pueblos originarios. Solo Cansarí, uno de los líderes obreros, resalta en el sector indígena y lo hace solo porque despierta a una conciencia similar a la de Cancio y sus amigos, desprovista de matices identitarios propios.

Pasan los años y los bananos generan beneficios, pero la Compañía ha ocasionado mucho daño al mundo. Parte de esos perjuicios se revierten a ella en forma de tres "plagas", que le causan millones de pérdidas. Estos tres fenómenos se explican en la obra con argumentos racionales, pero al mismo tiempo el texto establece, como en otros momentos, una relación intertextual con la historia bíblica. Como Faraón, tirano que torturaba al pueblo elegido explotándolo, pero que fue castigado duramente por Dios, la transnacional se hace merecedora de un correctivo por parte de las fuerzas de la naturaleza, en alianza con los trabajadores honrados, quienes también se levantan para liberarse.

La primera de las oleadas que tambalean al gigante del banano es una tormenta, cuyo paso destruye millones de plantas. La mano de Cruz, como se deja entrever, es en parte responsable del desastre climático. Así se cumple la profecía del inicio del relato, por la que el maestro se comprometió a ayudar desde las sombras. Sin embargo, la empresa se repone del embate y responde intentando controlar el tiempo atmosférico. Deshace las nubes que amenazan con precipitaciones, lo que ocasiona la sequía y la pérdida de las cosechas de las fincas aledañas a la Compañía.

La avaricia de los dirigentes provoca la segunda de las "plagas". Para ahorrar gastos y evitar el coste de los problemas sanitarios que padecen los indígenas, estos son sustituidos en las tareas de fumigación por avionetas. Ahora bien, desde el cielo el producto que vierten no alcanza por igual a todas las matas. Pronto, la "sigatoca", la enfermedad del banano, hace de las plantas unas víctimas exquisitas. La Compañía sufre millones de pérdidas a causa de este problema, pero se revitaliza otra vez colocando a los nativos en sus antiguos puestos.

El tercero y definitivo de estos castigos es la "invasión del comunismo", como catalogan, en su miopía, los dirigentes del emporio y sus aliados a la organización de los trabajadores en sindicatos y comandos de acción revolucionaria directa. Como ironiza el narrador, la referencia al comunismo no es más que una estratagema grotesca para ganarse a la opinión pública a través del miedo. En realidad, los trabajadores no se sienten parte de un movimiento ideológico concreto. De hecho, en la obra, los pocos mensajes tímidamente panfletarios que destacan están puestos en boca de un par de estudiantes, amigos de los revolucionarios, representantes del saber libresco. De lo que se trata realmente es de un movimiento que busca restituir el equilibrio y devolver la tierra a su justo poseedor: quien la hace producir. En el protagonismo que Candanedo otorga a las clases populares se aparta del nacionalismo panameño más clásico, de carácter elitista y jerárquico.

Los aires de revuelta se infiltran por los intersticios que la alargada sombra de la Compañía deja sin cubrir. Es cierto que el monstruo es eficaz en la represión, pero no es ubicuo: pequeños contubernios clandestinos, susurros, rumores de injusticias, van caldeando el ambiente $\mathrm{y}$, con el tiempo, creando el estado de conciencia preciso para que prenda la llama del levantamiento armado. Para cuando Cancio y sus amigos deciden infiltrarse como peones en la Compañía para comprobar la veracidad de los terribles relatos que han llegado a sus oídos, el malestar en las fincas es patente.

Rápidamente el líder de los de San Juan se hace cargo de la situación: el extranjero está volviendo a someter al nacional en el suelo propio, lo que demanda una respuesta drástica. 
Intentar la liberación por la vía legal es inútil: las autoridades están compradas. Siguiendo con lo aprendido en lances anteriores, comienza la merma. Ahora bien, pronto se da cuenta de que su estrategia no está siendo eficaz. El enemigo es, en esta ocasión, terriblemente poderoso y un hombre solo no puede vencer. Hace falta cambiar los planes, que han de tener un carácter colectivo. Cancio se muestra, por tanto, flexible y adaptativo, capaz de adecuar sus planes en función del desafío que encara: "Me parece que hasta de habla he cambiado aquí. Así no era antes. Más bruto, cuando solo me dedicaba a mermar" (222).

Aunque las actividades subversivas del líder y sus compañeros son prontamente detectadas por los guardianes de la Compañía, lo que provoca su despido, han tenido tiempo de forjar alianzas con otros trabajadores. Juntos todos los miembros de la red diseñan una ambiciosa estrategia de rebelión. No se trata de furia desmedida sin plan, como normalmente suelen ser los brotes de violencia rural. Se establece una lista negra de esbirros que mantienen en pie a la empresa en sus puestos claves, a los que se les piensa exterminar a todos el mismo día para tomar, después, las instalaciones y ponerlas a funcionar. Por supuesto, el consumo de alcohol decrece y las peleas se reducen entre los trabajadores, ya concienciados. Este incremento de las conductas responsables entre los peones despierta la atención de los capataces. Sin embargo, cuando dan la voz de alarma, ya es demasiado tarde. La obra concluye con la promesa de un nuevo día que iluminará la victoria de los justos, aunque esta no se narra: "Soplan vientos fraternales que preludian vientos más profundos que arrasarán las ruinas y unirán a los inocentes y a los nuevos hombres" (230). Después de la odisea, llega, por fin, el restablecimiento del orden natural, pero esta vez renovado, más maduro y contundente: "Todos hemos cambiado bastante porque tenemos un propósito" (222).

No debe resultar llamativo la elección de un final tan agresivo como este. Para el momento en que Candanedo escribe, se habían producido varios intentos de negociación por parte de Panamá con el objetivo de lograr mejores condiciones en su relación con Estados Unidos. Con todo, la mayor parte de esos encuentros habían terminado de manera insatisfactoria para el país centroamericano. Tal es el caso del Tratado General del 2 de marzo de 1936, en el que la potencia norteña ya no se comprometía a garantizar la independencia de Panamá, lo que fue visto por los nacionalistas como un paso más hacia una temida absorción. En los años previos a la gestación de la novela, Candanedo fue testigo de la rúbrica de otro de esos pactos de escasas garantías. En 1955 se firmaba el Tratado Remón-Eisenhower, por el que se hacía entrega de Río Hato a cambio de mayores beneficios económicos, un nuevo insulto para los nacionalistas, pues se menoscaba otra vez la integridad de la patria.

La permanencia de los estadounidenses acarreaba, además, infinidad de problemas a ojos de Candanedo. Explotación laboral, intervencionismo, injusticia... tanto en la Zona del Canal como en las empresas privadas en poder de los estadounidenses. El conflicto parecía muy lejos de solucionarse y, como un tumor maligno, removía las entrañas de muchos. No es de extrañar, por tanto, que el autor, en su grito amargo de protesta, aliente al compromiso y a la acción. Es evidente la desigualdad en el conflicto, lo que asusta. A causa de ello, este arriesgado movimiento ha de ser finamente calculado. Se perderán muchas vidas, pero la justicia de la causa garantiza su triunfo. Lo contrario - el estatismo - solo conduce a la pérdida de lo propio, devorado por el invasor insaciable.

\section{Conclusiones}

La otra frontera es un claro producto de su tiempo y de su lugar de procedencia, Panamá. Candanedo construye una narración en la que denuncia la situación de penuria y opresión que, una vez construido el Canal, vivían las comunidades campesinas en manos de los agentes del capitalismo occidental, capaz de transmutarse y presentarse bajo distintas formas, una invasión 
inaudita por su poder transformador y destructivo. Las cadenas del sometimiento solo pueden quebrarse si el pueblo toma conciencia y decide apostar por la acción colectiva revolucionaria contra el enemigo. Para configurar su narrativa, el autor recurre a varias matrices discursivas, populares en su tiempo, con las que forma un tejido conceptual desde el que han de interpretarse las distintas secuencias que configuran la trama. Una de las que más resaltan es la inversión de las nociones de civilización y barbarie, que pone de relieve la falsedad de la narrativa occidental del progreso y el desarrollo. No faltan tampoco los ideologemas extraídos del nacionalismo panameño, como la condena al dinero y lo foráneo. Asimismo, también se detectan algunas referencias al pensamiento izquierdista, pero tenuemente esbozadas, ya que el conflicto supera los espectros políticos tradicionales para situarse en un plano de carácter universal: la lucha entre el bien y el mal. Además, aunque la obra entronca claramente con los preceptos del regionalismo, se establecen conexiones intertextuales más amplias, en concreto con la historia bíblica. Destacan el castigo recibido por la adoración a la pecunia, el éxodo y la búsqueda de una tierra prometida, el enfrentamiento entre un David y un Goliat actualizados, las plagas de la Compañía y la redención final del pueblo justo. Asimismo, para perfilar a protagonistas y antagonistas — panameños y occidentales - Candanedo se apoya en los modelos prefigurados por el arielismo. Este es un conflicto en el que hay más en juego que la economía y la política. Dos formas de ser y de ver el mundo se enfrentan: lo espiritual y lo material, siendo el segundo claramente refutado. En su maniqueísmo, la novela no concede el más mínimo mérito a la presencia extranjera en el istmo ${ }^{13}$.

Toda esta riqueza intelectual latente en la obra conduce a un cuestionamiento de la narrativa del Pro mundo beneficio, vendida por occidentales y clase alta local como el destino de Panamá. Si bien la nación ha entregado todo, poco o nada ha recibido a cambio. La novela atestigua la decepción de unos panameños heridos en su propia tierra e imposibilitados de tener una vida digna, que les permita desarrollarse libremente y consolidar una conciencia robusta. De la galería de personajes que desfila por el relato, el que más sobresale es Cancio, el líder de los pobladores. Hombre lacónico y duro, es capaz de aprender y evolucionar en función de los obstáculos que debe superar. Él y su maestro Cruz son el epítome de la bondad y la justicia que alberga en su pecho el pueblo llano. Ellos se niegan a sucumbir ante los abusadores, por muy poderosos que sean. Con valentía y honor, enfrentan de cara los conflictos: "Hombres con conciencia de piedra y lodo. No se dejan domar. Retoñan siempre, viven sobre la muerte, superiores a la tragedia, airosos, imponentes en medio de tantos cadáveres" (58). Con todo, el protagonista es quizá el punto más débil de la novela. Ausente durante buena parte de la trama, apenas se deja conocer. En algunos momentos, resulta frío y lejano, poco menos que robótico. Resulta imposible identificarse con él. Tanto es así que podría catalogarse a La otra frontera como una novela de formación sin formación. El proceso de aprendizaje y concienciación que experimenta Cancio debe reconstruirlo el lector, aunque apenas se dejan pistas para ello. La falta de desarrollo psicológico del héroe, la trama simple y lineal y la falta de pericia técnica del autor, que rehúye la descripción de las escenas más complejas mediante astutas elipsis, dejan a esta novela en un plano de inferioridad frente a otras producciones canaleras como Luna verde de Beleño, que ha dejado una mayor impronta en el imaginario colectivo. Mientras otras continúan leyéndose y estudiándose tanto en Panamá como fuera, La otra frontera parece más bien relegada a ser material arqueológico para la crítica.

13. A diferencia de otras producciones como Luna verde, en la que el protagonista declara: "Antes de morir me dijo mi abuelo que en Panamá los estúpidos querían ser gringos y los inteligentes querían aprender inglés. Ahora me parece comprenderlo mejor. Acaso, intuyendo, quiso significar que debíamos aprender su técnica, sus adelantos, su mejor cultura, sus hombres de paz y desechar sus aberraciones de gringos. Es decir, que no debíamos ser gringos patanes y humilladores con su Gold y Silver Roll" (Beleño, 1999, 366). 


\section{Referencias}

Araúz, C. (2013). "Un sueño de siglos: el Canal de Panamá". En Debate, 21, 36-60. Disponible en: http://biblioteca.clacso.edu.ar/ar/libros/panama/cela/tareas/tar123/02arauz [última consulta: 16 de mayo de 2020].

Arosemena, J. (1973-1974). "La United Fruit Co: Enclave colonial panameño”. En Tareas, 27, 322.

Beleño, J. (1999). Luna verde. Panamá: Autoridad del Canal de Panamá

Candanedo, C. A. (1967). La otra frontera. Panamá: Ministerio de Educación.

Candanedo, C. A. (1972). Los clandestinos. Panamá: Ministerio de Educación

Castro, G. (2005). "Pro mundi beneficio. Elementos para una historia ambiental de Panamá". En Tareas, 120, 81-112. Disponible en: http://memoriacentroamericana.ihnca.edu.ni/uploads/media/tareas120.pdf [última consulta: 15 de mayo de 2020].

Fábrega, J. (1936). Crisol. Panamá: Star \& Herald.

Figueroa, A. (1982). Dominio y sociedad en el Panamá colombiano. Panamá: Editorial Universitaria.

Gómara, F. (1978). Historia general de las Indias. Caracas: Ayacucho.

Grinberg, V. y Mackenbach, W. (2006). "Banana novel revis(it)ed: etnia, género y espacio en la novela bananera centroamericana. El caso de Mamita Yunai". En Iberoamericana, 23, 162-176. Disponible en: https://journals.iai.spk-berlin.de/index.php/iberoamericana/article/view/926 [última consulta: 20 de mayo de 2020].

Ibáñez, F. J. (2018). La novela canalera. Historia y evolución de un tema fundacional en las letras panameñas. Madrid: UNED (tesis doctoral).

Isaza Calderón, B. (1994). El liberalismo y Carlos A. Mendoza en la historia panameña. Bogotá: Presencia.

Miranda, L. O. (1996). “Aproximación a César Candanedo, el escritor”. En Lotería, 406, 70-84.

Morales, E. (1928). Ensayos. Documentos. Discursos. Panamá: “La Moderna” de Quijano y Hernández.

-Pereira Burgos, C. (1974). "Experiencia y significado del movimiento de los trabajadores bananeros de Bocas del Toro en 1960". En Soler, R. (ed.). Panamá, dependencia y liberación. Costa Rica: EDUCA.

Pérez-Venero, M. (1978). "La novela canalera de Panamá: antecedentes literarios y sociales”. En Lotería, 264-265, 28-53.

Pizzurno, P. y Araúz, C. (1996). Estudios sobre el Panamá republicano (1903-1989). Panamá: Manfer.

Pulido Ritter, L. (2014, 6 de julio). "El Canal de Panamá: una historia literaria”. En El Semanal. Disponible en: http://www.jornada.unam.mx/2014/07/06/sem-luis.html [última consulta: 13 de mayo de 2020].

Pulido Ritter, L. (2007). Filosofía de la nación romántica. Panamá: Mariano Arosemena. 
Pulido Ritter, L. (2006). "Baltasar Isaza Calderón: el tamiz españolista contra el cosmopolitismo neocolonial". En Revista Panameña de Política, 2, 25-40. Disponible en: http://cidempanama.org/wp-content/uploads/2011/03/2-03Baltazar_Isaza-Luis_Pulido_Ritter.pdf [última consulta: 22 de noviembre de 2018].

Real de Azúa, C. (1976). "Prólogo”. En Rodó, J. E. Ariel. Motivos de Proteo. Caracas: Ayacucho.

Sarmiento, D. F. (1871). Facundo o civilización y barbarie en las pampas argentinas. París: Hachette y Cía.

Sinán, R. (1957). "Rutas de la novela panameña”. En Lotería, 23, 103-110.

Sutter, P. (1997). "Arrancarle los dientes al trópico: ambiente, enfermedad, y el Programa Sanitario de los Estados Unidos en Panamá, 1904-1914”. En Papeles de Población, Nueva Época, 24, 61-93. Disponible en: http://www.scielo.org.mx/scielo.php?script=sci_arttext\&pid=S1405-74252000000200004 [última consulta: 16 de mayo de 2020].

Tejeira, G. B. (1995). Pueblos perdidos. Panamá: Editorial Universitaria.

Tejeira, I. (2007). “«Pueblos perdidos», heridas abiertas”. En Maga, 60-61, 11-14.

Vásquez, M. (2007). "Entre Los clandestinos y El perseguido”. En Tareas, 125, 89-106. 